\title{
Animals Prospectus as a Legal Subject of Environmental Law In Indonesia (A Study of Ecofeminism)
}

\author{
Kadek Cahya Susila Wibawa ${ }^{1}$, Aga Natalis ${ }^{2}$ \\ \{kadekwibawa@lecturer.ac.id ${ }^{1}$, aga@usm.ac.id $\left.{ }^{2}\right\}$ \\ Faculty of Law, Diponegoro University, Semarang, Indonesia ${ }^{1}$, Faculty of Law, Semarang University, \\ Semarang, Indonesia ${ }^{2}$
}

\begin{abstract}
Rene Descartes' teachings influence the trend of environmental crises in the modern era causing harm to animals by human activities. In line with this thought, animals are considered only as properties instead of a subject of environmental law. Such thinking is the major criticism of ecofeminism. This study is a qualitative using juridical normative approach with the specification of descriptive-analytical research. The result found that there are three possibilities of legal status for animals in the study of environmental ethics and ecofeminism including status as a property for human needs, as property but its welfare must be guaranteed and as a legal subject. The animal status prospectus as a legal subject of environmental law in Indonesia in the study of ecofeminism can be done in two methods, namely reconstruction of environmental laws and court ruling.
\end{abstract}

Keywords: Legal Subject; Animals; Ecofeminism.

\section{Introduction}

The world of science has been influenced by the development of the mechanistic paradigm system popularized by Rene Descartes and Isaac Newton [1]. For those who believe in the mechanistic paradigm, the universe, and the organism is seen as a machine consisting of separate parts. For Descartes, plants and animals are considered only as machines and are used entirely for the benefit of humans [2]. In such a dimension of thought, the environmental crisis is something that cannot be avoided because modern humans see nature as an object that must be exploited. For example, environmental exploitation by humans which has an impact on animals is forest destruction. The forest ecosystems have decreased over time due to human intervention and it gets worse by illegal hunting which also threatens the lives of the animals in the forest.

The impact of environmental damage due to human activities that harm animals becomes a major problem because animals cannot hold accountable people who harm them before the court, this is because Descartes' teachings influence the study of law. Descartes' teaching led to the classification of animals' not as legal subjects but as property. Seeing such conditions, many of the scientists and legal practitioners are fighting for the establishment of legal personality (legal subjects) for animals. Status as a legal subject is considered to have an extremely important role and position in the field of law because it is the legal subject who later has legal authority, such as filing a lawsuit to court.

In December 2014, the New York State Supreme Court ruled in a case in which the Court was urged to enlarge the definition of common law tradition of the term "person" to grant legal rights to a chimpanzee named Tommy. The Nonhuman Rights Project (NhRP), founded by Steven Wise, has filed a series of cases in New York Courts seeking to characterize chimps detained in several US states, intending to protect chimpanzees' rights to integrity and freedom and allow them to seek rehabilitation efforts. This case is good for building legal subjects for non-humans.

The documents filed by the NhRP show that animals are autonomous beings with advanced cognitive abilities including episodic memory, self-awareness, self-knowledge, self-agency, deliberate communication, mental, empathy, imagination, working memory, decision making, symbolic culture, and use of tools. Legal arguments to expand the meaning of legal subjects 
beyond humans and legal entities are arguments that expand ethical considerations from humans who control the moral center.

Regulations concerning the position of animals in Indonesian law are contained in the Criminal Code, Civil Code, Law Number 5 of 1990 concerning Conservation of The Living Natural Resources and Their Ecosystems, and Law No. 18 of 2009 concerning Husbandry and Animal Health. Considering the human activities in environmental management that harm animals, it is regulated in Law 32 of 2009 concerning Environmental Protection and Management in Article 92 paragraph (1) stating that "In the framework of executing responsibility for environmental protection and management, environmental organizations shall reverse a right to file a lawsuit in the interest of environmental functions conservation". The law concerning Environmental Protection and Management does not specifically regulate animal rights, even in Article 1 Number 32 , it reduces the definition of a person who is identical to the meaning of a legal subject only to an individual or a business entity in the form of legal entity or not.

The issue of whether animals can be classified as legal subjects is a major topic of discussion in the study of law. Ecofeminism like other social movements emerged as social activism and intellectual criticism [3]. Ecofeminism combines the perspectives of feminism and the environment. Ecofeminism argues that women's domination and environmental degradation are the consequences of patriarchal domination with the face of capitalism in social life [4].

In contrast to feminist jurisprudence which limits only on the experience of women in law, ecofeminism jurisprudence aims to voice every silence caused by domination and exploitation of patriarchal societies in the form of western industrialists [5] by incorporating views and experiences in existing legislation, although these two schools can be included in the paradigm of critical theory et al, with the historical realism ontology that law is seen as a virtual reality which is formed by social, political, cultural, economic, ethnic and gender factors [6]. Eco feminist jurisprudence sees law not as a sovereign instrument to control society, but as a tool for social development, one of which is related to the establishment of the status of legal subjects in animals.

The problems that need to be studied in this research is: what is the legal status of animals in the study of environmental ethics and the perspective of ecofeminism? And what is the animal status prospectus as legal subjects of environmental law in Indonesia in the study of ecofeminism? The objective of this study is to find out and analyze the status of animals as legal subjects in the study of environmental ethics and ecofeminism and to find out and analyze the animal status prospectus as legal subjects of environmental law in Indonesia in the study of ecofeminism.

\section{Methods}

This study uses a qualitative method with a normative juridical approach. This study can be specified as analytical descriptive because it elaborates, describes, or reveals the status of animals as legal subjects, then it will be linked to various regulations and legal theories that apply and their implementation regarding the problems under study. The data collection technique used is a literature study and documents to discuss the topic of the problem in more detail and can be held accountable for scientifically.

\section{Results and Discussion}

\subsection{Legal Status for Animals in Environmental Ethics and Ecofeminism Studies}

Environmental ethics is interpreted as a critical reflection on norms and values or moral principles that are commonly known in relation to the environment and a critical reflection on the way humans perceive humans and nature as well as behavior that comes from this perspective [7]. Various schools of environmental ethics are quite popular, such as anthropocentrism, animal rights, animal welfare, and ecofeminism. These various schools dominate the thought about the status of animals in the study of law. One thing that makes the difference between these various schools is related to the recognition of whether animals have moral status or not. 
Every entity has moral status if and only for its interest and it is morally important to some degree in the interest of the entity itself. The presence or absence of moral status in animals will have implications for their status as legal subjects. If a living thing is considered to have moral status, then that living things can be said to be a legal subject, and living beings considered a legal subject means that they have rights and authority without exception, this is what is called the legal authority to have rights and obligations.

The granting of moral status is not because the entity is beneficial to other entities, but because their needs to have a moral interest and the rights of an entity itself. According to Warren, the moral degree is unlimited, depending on its function in a moral community [8].

The philosophical debate about the moral status of animals between the Utilitarian Theory pioneered by Peter Singer and the Rights Theory of Tom Regan and Cristopher D. Stone. Opposing position in terms of the moral status of animals, Peter Singer argues based on a combination of behavioral, physiological, and evolutionary evidence that animals have an interest, at least an interest not to suffer, and therefore a feeling less being (the ability to experience pain and pleasure) does not need to be considered morally [9].

Peter Singer stated that organisms are organized in a moral hierarchy, where the lowest group does not deserve moral consideration and the top group deserves more moral consideration than the latter. The group is divided into three groups among others are: (1) groups of animals that are aware of their existence, which includes animals that are aware of their existence and prefer to continue to live properly, animals that experience pain and pleasure, animals that are aware of their existence and context, animals that prefer to have a good life, and animals that prefer to stay alive; (2) animals that are not aware of their existence, which includes living animals but does not have the idea to continue to live in the future, animals that can feel pain and pleasure, animals that prefer to avoid pain, and animals that like to experience pleasure; (3) and morally incapable organisms and inanimate objects are therefore do not deserve to be considered morally because they do not deserve to speak of how to treat them well or badly and they cannot feel them.

Tom Regan has a quite different view from Singer. Regan with his alternative opinion begins by rejecting utilitarianism. For Regan, utilitarianism failed to respect what came to be known as "Separateness of Persons"[10], for example following the utilitarian view that slavery is wrong only because it fails to maximize the good, not because it disturbs the dignity of others. That it was justified to harvest organs from another person to save the two others. Regan came up with one of the first animal rights theories in his book "The Case for Animal Rights", published in 1983. Regan claimed that at least some animals should be recognized to have innate value and moral rights. Regan creates basic life requirements that cover more than just violence.

The animal rights include the right not to be considered as property. Gary L. Francione argues that animals have rights, namely the right not to be treated as property [11]. Gary points out that many approaches to animal care without challenging the status of animals as resources for humans. Gary described rights as merely a way of protecting interests. The perception that feelings (awareness and perception) alone must be the only criterion for the right not to become property (property rights). Garner believed that animals have no interest in freedom and even though animals have the interest to live, it is a lesser interest than humans [12]. Garner focuses on unnecessary suffering (the principle of human care) because that's something most people already agree on. There is one interest that Garner believes is equal between humans and animals and that is not to suffer. Legal rights were popularized by Steven Wise who proposed to win animal rights through United States law [13]. Wise believes that the Common Law approach will work because it has flexible and adaptable nature. Other animal rights according to the rights theory including the right not to be paralyzed, the right not to be harmed by violations, the right not to be deprived of the pursuit of the basic goods of life, the right not to be traumatized by human activities, the right not to be placed at risk of serious illness in sporting activities (such as cockfighting and horse racing), and the right not to be placed at risk of serious illness, injury or death in human products testing (cosmetics, pharmaceuticals, and chemicals).

The rights that animals have as subjects, according to Christopher D. Stone, will have meaning for the rights holders if they meet several conditions. First, the right obligates government officials or agencies to assess and study activities that contradict or violate this right. Second, the right holder can file a lawsuit on their behalf if their rights are threatened. Third, in determining 
legal remedies, the court should consider the loss of the right to it. Fourth, the legal remedies should be provided for the benefit of right holders [14].

In the common law system, the second condition stated by Stone, namely "the right to file a lawsuit" is referred to as "legal standing". For humans, having rights will not cause difficulties in voicing, defending, and realizing their rights in their interests in court proceedings and administrative processes because they can communicate or speak. However, Stone rejected that view by using the corporate analogy, private, and public legal entities that also cannot have the ability to communicate. By using the concept of guardianship, then Non-Governmental Organizations (non-government associations) can become guardians on behalf of animals. In countries with the continental European system, the concept of the right to file a lawsuit for nongovernmental organizations has also been formulated in legislation. In Indonesia, the right to file a lawsuit for Non-Governmental Organizations is regulated in Article 92 of Law no. 32 of 2009 concerning Environmental Protection and Management [15].

The animals suffering that are universal, such as the increasing extinction of wild animal species, a large scale of domestic animals exploitation for food production or other purposes, the use of animals for experimentation, while many others are deprived of their liberty for other purposes (such as entertainment). According to Tom Kelch, there is a need for a global animal law worldwide. Modern global law must be adhered to and pursued in an integrated and cross-cultural manner, as a strategy to promote the interests of animals globally [16].

Anthropocentrism is a school of ethics that sees humans as the center of the universal system [17]. Humans and their interests are considered to be the ones who determine the ecosystem order and in the policies taken concerning nature, either directly or indirectly. The highest value is human beings and their interests. The anthropocentrism argument is found in the Aristotelian tradition as developed by Thomas Aquinas with the main focus on the Chain of Life (The Great Chain of Being). According to this argument, all life on earth forms and is in a chain of perfections of life, from the simplest to the Most Perfect Being that is God. In the chain of perfection of life, humans occupy the position as the closest to the Most Perfect Being, it means that humans are at the top of the chain of creation so that they are considered superior to all other creations, including all living beings.

Rene Descartes emphasized that humans have a special place among all beings because humans have a soul that allows them to think and communicate with language, on the other hand, animals are beings that are inferior to humans because animals only have bodies which Descartes considers just as an automatic moving machine. Descartes' statement is known as Cogito, ergo sum (I think, therefore I am). In line with this statement, Immanuel Kant stated that only humans are rational beings, so humans are allowed to use non-rational beings such as animals to achieve human life goals [18] because non-human beings and all other natural entities including animals do not have a sense so that they are not obliged to be treated morally. Based on this understanding, humans have no moral obligation and moral responsibility towards other living beings.

Deep ecology was coined in Scandinavia, the result of discussions by Arne Naess and her colleagues Sgimund Kvaloy and Nils Faarlund. Naess was inspired by Spinoza's Metaphysics which rejected the existence of Atomistic Individualism, [19] because it only considered that humans are individuals who have separate essences. Naess' belief places that animals have moral status because a person must be oriented and act towards his relationship with the world (including animals) must be based on a platform; the life and welfare of humans and animals specifically continue to develop and have value within themselves.

Ecofeminism is a branch of feminist philosophy that sees the relationship between oppression and the environment as the basis for its analysis and practice [20]. The concept of ecofeminism was popularized by French writer, Francoise d'Eaubonne, in his book entitled "Le Feminisme ou la Mort" in 1974. Ecofeminism claimed that a feminist should not put women in a dominant position of power, but rather need an egalitarian and collaborative society where there is no dominant group. The analysis of ecofeminism explores the relationship between women, nature, culture, religion, literature, and iconography as well as discusses the parallel relationship between the oppression of nature and oppression of women [21]. Parallel relationships are not limited seeing women and nature as property, seeing men as curators of culture and women as curators of 
nature, and how men dominate women and humans dominate nature. Ecofeminism emphasizes that both women and nature must be respected.

To build a relationship between women, nature, and oppression of animals, ecofeminism comes with its various schools. Spiritual ecofeminism does so by citing numerous examples of the worship of nature in the form of a "Goddess" in primitive legal societies [22]. The oppressive traditions of patriarchy are not only hostile to nature and natural resources, but also a large extent connected to it, such as animals. Cultural ecofeminism explains the basics of maternal care and affection, as well as associating traits, natural values, and compassion. Hence, the patriarchal mindset exploits not only women, nature, or the third world, but also any part of the earth that is weak and unable to do so against male chauvinism [23].

\subsection{Animal Status Prospectus as a Legal Subject of Indonesian Environmental Law in Ecofeminism Studies}

According to Sudikno Mertokusumo, legal subjects are all beings that can obtain rights and obligations from the law [24]. A similar opinion was stated by Subekti which said that the legal subject is the rights holder or the subject in law, namely people. While in Black's Law Dictionary, the definition of a legal subject is formulated as one that owes allegiance to a sovereign and is governed by his laws. The natives of Great Britain are subjects of the British Government. Men in free governments are subjects as well as citizens; as citizens, they enjoy rights and franchises; as subjects, they are bound to obey the laws.

The term legal subject is derived from the Dutch language, rechtsubject or legal subject in English. In general, rechtsubject is defined as supporting rights and obligations, namely humans and legal entities. Therefore, a legal subject is anything that has legal authority, has rights and obligations in legal actions. Legal subjects are closely related to legal proficiency or rechtsbekwaam, and authority in law or rechtsbevoegd. A legal subject is every person who has rights and obligations in legal relationships [24].

In December 2014 the New York Supreme Court rejected a lawsuit from the Nonhuman Rights Project (NhRP) founded by Steven Wise by citing what was formulated in the Black's law dictionary, that people are anyone who can execute rights and legal obligations. The court considers chimpanzees as non-legal subjects because chimpanzees do not have legal rights. This argument is also based on social contract theory, that the notion of rights is related to the imposition of social obligations and duties. Animals cannot fulfill any social responsibility, which is the reason why there is no need to confer with chimps on legal rights.

Regulations concerning the status of animals in environmental law in Indonesia are contained in Law 32 of 2009 concerning Environmental Protection and Management in Article 1 Number 32 which regulates that everybody shall be an individual or business entity whether in the form of legal entity or not. This regulation has implications for animals because the definition of a person who is inclined towards the notion of a legal subject regulated in the law is simplified only to individual or business entities. This is supported with the explanation of Article 2 Letter I that what is meant by "the principle of biological diversity" is that Environmental Protection and Management must pay attention to integrated efforts to maintain the existence, diversity, and sustainability of living natural resources consisting of vegetable natural resources and animal natural resources together with the surrounding non-living elements as a whole forming the ecosystem. In this article, animals are categorized as a resource for humans, but what is unique about this article is the word ecosystem.

If it is an ecosystem, there should be no differentiation between the various components. An ecosystem always leads to an "equilibrium" state, which means that all components in the ecosystem are in a harmonious and stable interaction so that the ecosystem is formed in an orderly process and runs continuously. In short, in such an ecosystem concept, all components are legal subject. Similar to the definition of a legal subject that emphasizes everything that can be subject to legal rights and obligations, if it is combined with the concept of an ecosystem, then each component can be subjected to rights and obligations. For example, the right not to be exploited and the obligation to maintain the balance of the ecosystem.

The prospectus for the establishment of the subject of environmental in animals in Indonesia can be carried out through 2 (two) mechanisms including reconstructing the law regulating the environment and through a court ruling (judge law) mechanism. In Indonesia, laws and regulations 
and a court ruling are both interpreted as sources of law, even though as adherents of the civil law system, laws and regulations are considered as the main source of law.

An example of a country that uses court ruling to establish legal subject status in animals in India. In an external ruling, the Punjab and Haryana High Courts have ruled that animals have legal rights like humans and declare citizens as "guardians of the animal kingdom" and are tasked ensuring the welfare and protection of animals such as prohibiting the use of animals to tow vehicles during winter and summer season. The use of sticks, harnesses, or yokes with nails, knobs, projections, and sharp objects is also prohibited to avoid bruising, swelling, abrasions, and serious pain to the animal.

To avoid discomfort to the animals, the Judge also directed the police to ensure that animaldrawn cart is provided with the "right of way". Its use is also limited to 9 (nine) hours a day in aggregate and no more than 5 (five) hours without rest. Animals are considered entities that are equated with legal entities because they have personal rights, franchises, duties, and obligations like humans, such as having the right to file a lawsuit in court. Animals including poultry have the right to life, body integrity, honor, dignity and cannot be treated as property. All citizens throughout Haryana are declared to have obligations towards animals as loco parentis, namely responsibility for a child without the presence of parents.

Apart from India, several countries exclude animals from property status, such as Austria, Germany, Switzerland, and Romania which use a statutory approach. However, it needs to be realized that the statutory approach requires a large amount of political and public support because this support will have a quick and effective impact on changing the status of animals from property to being a legal subject. The regulation concerning animals in Indonesian environmental law is based on the political law of Law 32 of 2009 concerning Environmental Protection and Management that the decreasing quality of the environment has threatened the continuity of human life and other living beings so that all parties involved can carry out a serious and consistent environmental protection and management. In this understanding, animals as an element of the environment can be damaged or extinct which affects human life. This understanding is consistent with the statement of Peter Singer that if anything can feel pain then it must be protected. In short, the law only covers animal welfare.

Even though the law concerning the environment has regulated animal welfare, this law has many limitations. For example, the law does not prevent suffering from all forms of harm to animals and regulates exploitation rather than prohibits it and the law does not apply equally to all animal species. The limitations of the law mean that it provides only "Band-Aid" rather than solutions for the problems. Such laws are full of patriarchal nuances which are the major criticism of ecofeminism.

Ecofeminism begins with the analysis that the effort maintaining masculine traits in law such as environmental regulations will only perpetuate domination, violence, exploitation, aggression, and humiliation of nature which is the root of exploitation of animals, experts of Eco feminists declare a new ethical legal framework which is more radical. There are 6 methods of ecofeminism to provide criticism on the more traditional Western philosophical views in understanding the position of animals in law which includes emphasizing that the western philosophical view of man as a separate rational agent and superior to nature has failed to place a proper position for animals in law; Eco feminists make interconnections between lawful violence against women, nature, and animals; traditional western philosophy that influences law by playing with language in creating, maintaining, and perpetuating the interconnected exploitation of women and animals; Eco feminists show how dualism as the basis of canonical philosophy such as culture versus nature and mind versus body which is historically gender-neutral has connected men and cultures with superior minds and women and animals that have lower natures and bodies; Western philosophy that influences law has placed women and animals in a system that mutually reinforces unjust domination practices by law, especially related to the practice of sexism and speciesism; and such laws raise the question of the absence of a gender perspective in traditional animal ethics by creating positions on incomplete and inadequate animal mistreatment.

Ecofeminism then rejects masculine approaches to animal liberation, such as the philosophy popularized by Peter Singer and Tom Regan, because it focuses on abstract and impartial moral issues for animals. For example, the experts of Eco feminists have criticized Regan's focus on 
animal rights because the concept of rights is seen as encouraging or prioritizing male experience by promoting isolated individualism and autonomous statement, then denying the close relationship between humans and other beings such as animals [25]. Eco feminists go further from the philosophy of Tom Regan and Peter Singer, as they provide a gender perspective on these practices in animal protection in general. Ecofeminism approach to animals prioritizes emotions, relationships, sympathetic responses, and instincts of care while rejecting the use of rational and fair moral reasoning to determine what morality should be done with animals. Instead of calculating the debt of humans to animals, Eco feminists ordered to establish laws based on human experience and the real world where humans live. The law that will be applied must consider the close relationship between humans and everything outside themselves, including animals by promoting sympathy. Given that the law has a function as a tool of social and bureaucratic engineering, then such laws will guide humans to ethical treatment of animals. This approach is known as the ethics of care.

Lawmaking relating to animal care ethics proposes that the attention of lawmakers should be directed to what animals say to humans, rather than what humans say to other humans about animals. In the article "Feminism and the treatment of animals: From care to dialogue" express a new emphasis on dialogue with animals by studying their communication systems, reading the animal's phenomenological body language, and taking that communication seriously in the ethical decisions of lawmakers [25].

For ecofeminism, it is not only animals that must be grouped as legal subjects, but all components in the ecosystem are legal subjects. Grouping one entity but the others into a legal subject is discriminatory, therefore the understanding of the subject is comprehensive. The urgency of the status of legal subjects for everything in the ecosystem is that all components appreciate and respect each other because all components are the guardians of the balance of the system. A universe without animals is certainly not balanced, humans without plants will cause humans to become extinct, natural damage will cause women to suffer, nature without humans will not be balanced, etc.

Making all components in an ecosystem including animals to be a subject of environmental law based on ecofeminism in Indonesia will certainly have many challenges. These challenges include two things, namely challenges to the status of legal subjects in animals and challenges in using ecofeminism studies. This challenge arises because the legal culture of Indonesian society has a strongly patriarchal culture. According to Mochtar Kusumaatmadja, when the law is categorized as a social principle, then the law cannot be separated from the applicable values [26], so it can be said that law is a reflection of the standard values adopted by society. In a patriarchal society, the character and implementation of the law is a reflection of masculine values, so that the character of the law will be patriarchal and has the potential to cause discrimination against women, nature, and marginalized communities because the law that is enforced will always maintain the dominance of men over women and the dominance of humans to nature. The patriarchal character in the field of law can be felt in the traditional school of law, namely legal positivism, which sees law as an objective reality and reality is a foothold for law enforcers, therefore such environmental law must be reconstructed to create a just law for all components of life [27].

Furthermore, there will be debate regarding the status of legal subjects in animals because animals are considered legally unable to defend their rights and obligations before the court. In fact, they can use the understanding that animals are incapable of legal subjects or miserable personae, as in the case of children under kuratele. Miserable personae mean a legal subject who does not have the authority to act [28]. The authority to act is a skill recognized by law to carry out legal acts itself, therefore the state through the legislative body must create a special miserable personae institution for animals to support their status as legal subjects. The establishment of such laws is consistent with the principle of ecofeminism, that establishing the status of legal subjects in animals does not mean that animals must have the same constitutional rights as humans because ecofeminism rejects general matters but focuses on specific issues because all components in life are equal but different. Each entity has different characteristics and needs, therefore the state must embrace all interests through a just law and be sensitive to the different needs between entities in life. 
The ecofeminism logic is about the relationship between animals and humans in the making of laws and regulations by using the parable of a fish in the pond of a royal palace. The King loved the fish dearly, with great affection, the King wanted to ensure great happiness for the fish. The King was wealthy and prosperous. Everything the King wore was made of gold, for the entire palace was endowed with attractive gold ornaments. One day, the King came up with the idea that if he wanted to make the fish truly happy and prosperous, then he must surround the fish with gold just like him. The King ordered to take the fish from the pond and put it on a gold plate. The following morning, when the king went to see the fish all his joy was gone because the fish had died.

The story depicts the human being played by the King as a lawmaker in this case the government which wrongly determines the legal norms that are good for all creatures, so they think that all happiness or welfare is universal. The problem is that the concepts of development, prosperity, happiness, and so on are completely pure and vary from place to place, being to being, and community to community. Ecofeminism assumes that development or empowerment cannot be forced, because it can only be encouraged. Therefore, to build and incorporate the concept of ecofeminism in the field of law, eco-feminism emerges as an ecofeminism jurisprudence to uphold and establish laws to regulate the development of living beings through the preservation of originality and efforts to ensure that the law is progressive for all beings.

Adopting the teachings of ecofeminism which is a branch of the philosophy of feminism in shaping the status of the subject of environmental law in Indonesia will certainly lead to various challenges, such as rejection because ecofeminism is considered a western and liberal thought so that it is incompatible with Indonesia with the Pancasila ideology. This statement can be refuted by looking further into the teachings of ecofeminism. Ecofeminism is not limited to any ideology, it exists to fight for justice for anyone who is harmed by the influence of patriarchy in terms of forming relationships between humans and nature. Ecofeminism has a spiritual side that is unique to the Indonesian culture. In line with Pancasila, ecofeminism develops an understanding of spirituality based on nature and all related components of life. The spirituality aspect of ecofeminism is not related to one particular religion but is centered on the values of caring, compassion, and non-violence. This concept of ecofeminism can be found in various cultures of Indonesian society, even though most Indonesians do not realize that these cultural practices are part of ecofeminism.

An example of the spirituality of ecofeminism that is practiced in Indonesian society is the Dayak Benuaq community that views nature not as an asset or wealth (property) but as a common or shared house [29]. The concept of a common or shared house is seen in every ceremony that precedes certain activities related to utilizing the forest, where there is always an element of a premise or asking permission from the spirit of the forest for the utilization of the forest. The sound of certain birds or animals is a means of communication between humans and natural inhabitants. Even the land and forests, which in Dayak Benuaq terms are referred to as talutntanaq, become an inseparable unity from humans and other beings that encompass all components of the ecosystem, including humans, flora, fauna, etc.

\section{Conclusion}

The legal status of animals in the study of environmental ethics and ecofeminism, that environmental ethics is interpreted as a critical reflection on norms and values or moral principles that are commonly known in relation to the environment and critical reflection on the way humans perceive humans and nature. Environmental ethics focuses on the issue of whether animals have a moral status that affects the way humans should treat animals whether as property or legal subjects. From various schools of environmental ethics, there are three possible positions of animals in law, namely as a property that is controlled for the benefit of humans, as property but humans must guarantee animal welfare through laws governing animal welfare, and as legal subjects who have legal rights and obligations. For ecofeminism, animals are legal subjects so that animals must be protected from all exploitation activities by human activities. 
The animal status prospectus as legal subjects of environmental law in Indonesia in the study of ecofeminism can be done through changing environmental legislation or through court ruling mechanisms to establish legal subject status in animals. The ecofeminism criticism concerning environmental legislation that discriminates against animals begins by analyzing that the effort maintaining masculine traits in laws such as statutory regulations will only perpetuate domination, violence, exploitation, aggression, and humiliation of nature which is the root of exploitation of animal. Animals are legal subjects who are incapable or miserable personae, as in the case of children under kuratele, therefore the state must create a special institution for miserable personae to support the status of legal subjects in animals.

\section{References}

[1] Y. D. Alfia, I. Triyuwono, and A. D. Mulawarman, "Visi Antropokosmik Membangun Kerangka Prinsip Teoretis Akuntansi," in International Conference Thougts on Human Scieences in Islam, November, 2016.

[2] J. Leiber, "Descartes: The Smear And Related Misconstruals," J. Theory Soc. Behav., vol. 41, no. 4, pp. 365-376, 2011.

[3] G. Chandra Mondal and P. Majumder, "Ecofeminism: Encouraging Interconnectedness with Our Environment in Modern Society," Am. J. Educ. Res., vol. 7, no. 7, pp. 482-484, 2019.

[4] F. Sanati, H. N. Hatamian, and T. S. Tengku Mahadi, "An Analysis of the Ecofeminist Viewpoint on Industrialization and Environmental Degradation in Starhawk's The Fifth Sacred Thing," J. Sustain. Dev., vol. 4, no. 4, pp. 86-90, 2011.

[5] A. Sahoo, "Ecofeminist Jurisprudence: A Much Needed Change in the Perception of Law," Int. J. Law Leg. Jurisprud. Stud., vol. 2, no. 6, 2015.

[6] E. Indarti, Diskresi dan Paradigma: Sebuah Telaah Filsafat Hukum. Semarang: Badan Penerbit Universitas Diponegoro, 2010.

[7] S. Sukmawan and M. A. Nurmansyah, "Etika Lingkungan dalam Folklor Masyarakat Desa Tengger," Literasi, vol. 2, no. 1, pp. 88-95, 2012.

[8] M. A. Warren, "The Moral Significance Of Birth," Ethics Reprod., vol. 4, no. 3, pp. 46-65, 1989.

[9] D. DeGrazia, "The Moral Status Of Animals And Their Use In Research: A Philosophical Review.," Kennedy Inst. Ethics J., vol. 1, no. 1, pp. 48-70, 1991.

[10] L. Semrau, "Christopher Woodard: Taking Utilitarianism Seriously," J. Value Inq., no. 0123456789, 2020.

[11] G. L. Francione, “Some Brief Comments On Animal Rights,” Anim. Front., vol. 10, no. 1, pp. 29-33, 2020.

[12] A. T. Schmidt, "Why Animals Have An Interest In Freedom," Hist. Soc. Res., vol. 40, no. 4, pp. 92$109,2015$.

[13] A. Fernandez, "Legal History and Rights for Nonhuman Animals: An Interview with Steven M . Wise," Dalhous. Law J., vol. 41, no. 1, 2018.

[14] T. Bryant, "Animals Unmodified: Defining Animals/Defining Human Obligations to Animals," Univ. Chic. Leg. Forum, vol. 2006, no. 1, p. 6, 2015.

[15] N. Listiyani and M. Yasir Said, "Political Law On The Environment: The Authority Of The Government And Local Government To File Litigation In Law Number 32 Year 2009 On Environmental Protection And Management," Resources, vol. 7, no. 4, pp. 0-13, 2018.

[16] T. G. Kelch, "Towards Universal Principles for Global Animal Advocacy," Transnatl. Environ. Law, vol. 5, no. 1, pp. 81-111, 2016.

[17] T. Gansmo Jakobsen, "Environmental Ethics: Anthropocentrism and Non-anthropocentrism Revised in the Light of Critical Realism,” J. Crit. Realis., vol. 16, no. 2, pp. 184-199, 2017.

[18] J. Birch, "The Place Of Animals In Kantian Ethics," Biol. Philos., vol. 35, no. 1, pp. 1-11, 2020.

[19] P. Valenzuela, "The Metaphysical Bond between Natural and Human Beings: an Argument from Aquinas's Natural Law for justifying Environmental Ethics," Forum Suppl. to Acta Philos., vol. 5, pp. 299-312, 2017.

[20] L. F. Zein and A. R. Setiawan, "General overview of Ecofeminism," LAxARS, no. August, pp. 1-10, 2016.

[21] G. Vandermassen, "Can Darwinian Feminism Save Female Autonomy And Leadership In Egalitarian Society?," Sex Roles, vol. 59, no. 7-8, pp. 482-491, 2008.

[22] P. S. Sharnappa, "Reconstructing ecofeminism: A study of Kamala Markandaya's nectar in a sieve," Cogent Soc. Sci., vol. 2, no. 1, 2016. 
[23] M. Estévez-Saá and M. J. Lorenzo-Modia, "The Ethics and Aesthetics of Eco-caring: Contemporary Debates on Ecofeminism(s)," Womens. Stud., vol. 47, no. 2, pp. 123-146, 2018.

[24] D. H. Prananingrum, "Telaah Terhadap Esensi Subjek Hukum: Manusia Dan Badan Hukum," Refleks. Huk. J. Ilmu Huk., vol. 8, no. 1, pp. 73-92, 2014.

[25] C. J. Adams, "Ecofeminism and the Eating of Animals," Hypatia, vol. 6, no. 1, pp. 125-145, 1991.

[26] A. W. Wibisana, "Teori Mochtar Kusumaatmadja tentang Hukum Sarana Pembangunan Masyarakat Sebagai Teori Jalan Tengah Antara Aliran Mazhab Positivisme Dengan Mazhab Sejarah,” Themis, vol. 9, no. 1, pp. 961-973, 2017.

[27] A. Natalis, "Reformasi Hukum Dalam Rangka Mewujudkan Keadilan Bagi Perempuan," J. Crepido, vol. 2, no. 1, pp. 11-23, 2020.

[28] E. A. Q. Adriano, "Natural Persons, Juridical Persons and Legal Personhood," Mex. Law Rev., vol. 8, no. C, pp. 101-118, 2015.

[29] H. Rahmawati, "Local Wisdom dan Perilaku Ekologis Masyarakat Dayak Benuaq," Indigenous, vol. 13, no. 1, pp. 72-7, 2018. 